\title{
Congenital dermal sinus を伴つた馬尾神経
} 皮様腫の一治験例

山口大学医学部整形外科
千 束 福 司*.服 部
河 合 伸 也 奖
柴 田 輝 明 - 荒 木 茂
正
中 似一郎

\section{One case of cauda eduina dermoid cyst associated with conngenital dermal sinus}

by

F. Senzoku, S. Hattori, S. Kawai, K. Doi, T. Shibata S. Araki and Y. Tanaka

Department of Orthopedic Surgery, Yamaguchi University School of Medicine.

\begin{abstract}
Congenital dermal sinus communicated with the spinal canal is rare and fourteen cases have been reported in Japan. We would like to report one case of this disorder. Our case is a five-year-old girl. She has a congenital dermal sinus (associated with dimple, pigmentation and hair.) in the sacral region. Roentgenogram showed spina bifida occulta in the second sacral vertebra. Myelography showed complete obstruction below the level of the third lumbar vertebra.

Laminectomy and removing of cyst were carried out. Symptomes are improving of ter surgery.
\end{abstract}

Congenital dermal sinus (以下 C. D. S.) は 1880 年 Hodges ${ }^{8)}$ により始めて記載された。頭蓋 るいは脊椎の背部皮膚正中線上にあり, 内腔が重層扁 平上皮細胞に被われた発生異常に基づく奇形である. 時に頭蓋や脊椎管内に達し，先天性腫瘍すなわち表皮 様腫や皮様腫と直結する. 欧米では C. D. S. 亿脊椎 管内皮様腫を伴った症例を 1929 年 Sharpe \& Sha$\mathrm{rpe}^{22)}$ が報告して以来数多くの報告がみられるが，本 邦では 1957 年宇田川 ${ }^{24)}$ が C. D. S. 亿脊椎管内表皮 様腫を伴った症例を報告して以来文献上 14 例を渉椫 しうるにすぎない，最近著者は仙椎部に C. D. S. を 伴った馬尾神経皮様腫の 1 例を経験したので 報告す る.

\section{症例}

5 才の女児で, 主訴は歩容異常. 家族歴, 既往歴, 妊娠及び出産歴に特記すべきことなく，生後順調に成
長して来たが， 3 才 9 力月の頃仙椎部の皮䖉陥凹部に 一致して圧痛を認め, しかも踵部をつけて歩かないて とに気付くも放置した. 5 才になっても同様の症状が 続き, 歩行速度も緩慢で, 脊椎運動は著明に制限さ れ，膝関節伸展位では座位をとることが出来なかっ た. 某医を受診, 終系症候群なる診断下に当科紹介と なった。

入院時所見 仙椎部の高さの皮膚正中線上に多毛を 伴う色素沈着を認め, その中央部に直径 $2 \mathrm{~mm}$ 大の 皮膚陷凹が存在し，陷凹部に圧痛を認めた（図 1 ）。 金椎運動は著明に制限され，歩幅が狭く踵部をつけて 歩けなかった. しかし神経学的異常所見は存在しなか った. X線所見では椎弓根間距離の拡大, 第 2 仙椎に 潜在性脊椎披裂が認められた. また後頭下穿刺による ミエログラムでは第 3 腰椎々体上縁で後方からの圧迫 像が認められ，以下完全ブロックとなった（図 2 ）。

以上皮膚陥凹, 潜在性脊椎披裂及びミエログラムの 


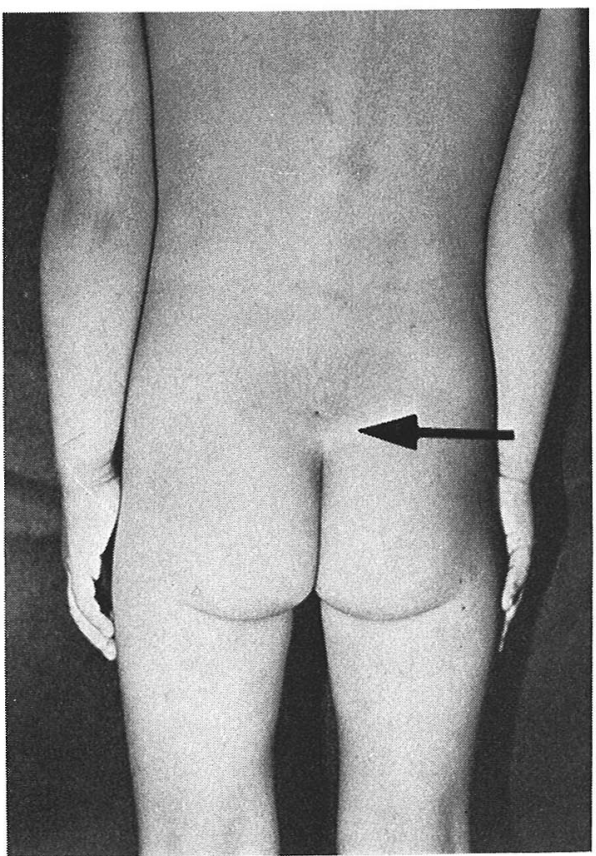

図1 仙椎部皮膚正中線上に多毛を伴う色素 沈着を認め中央に皮简陥凹（ $\rightarrow$ 印）

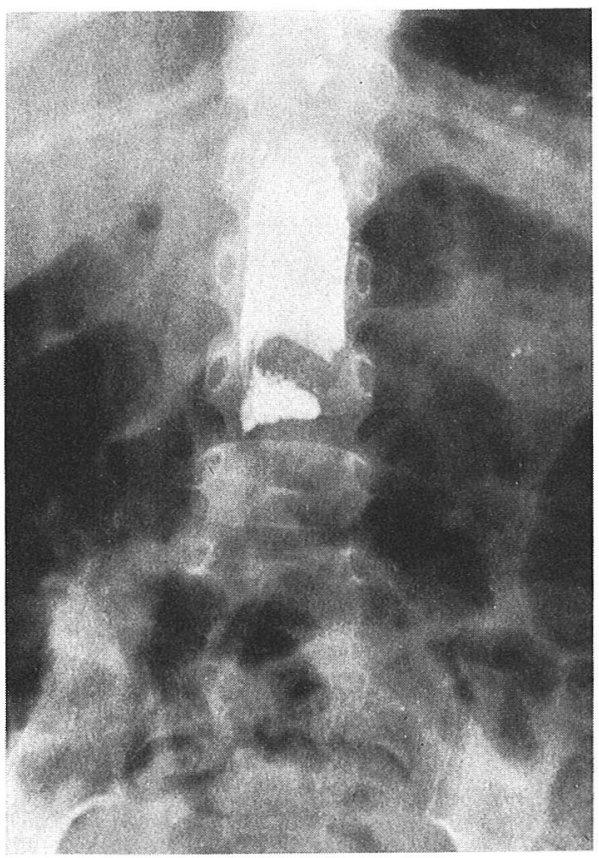

図2 脊䯣造影所見 第 3 腰椎以下完全ブロック
所見より仙椎部の皮膚病変と何等かの関係を有する馬 尾神経腫瘍を疑い腫瘍摘出術を施行した.

手術所見 腹卧位で第 2 腰椎より第 2 仙椎に至る椎 弓切除を行ない硬膜を縦切したところ髅液の流出はな く, 腫瘍が脊惟管腔全体に拡がり，第 3 腰椎より第 2 仙惟に至る露腫状で薄い被膜でおおおれ，馬尾神経を 圧迫し迷入していた，末梢部においては索状となり， 第 2 仙惟部の高さで硬膜を貫佊膚陥凹部と連絡し ていた（図 3 ）。この索状物は皮虞表面より $3 \mathrm{~mm}$ の 深さで $1 \mathrm{~cm}$ にわたって閉塞し，径は $4 \mathrm{~mm}$ であっ た、腫瘍と脊髄との境界が不明膫であったため末梢側 の索状物より摘出すると多量の毛髮を有する粉溜様の 内容物で，可及的郭清し漸次摘出した，病理組織では 皮様腫であった，洗浄後止血を十分行ない硬膜を縫合 して創をとじた.

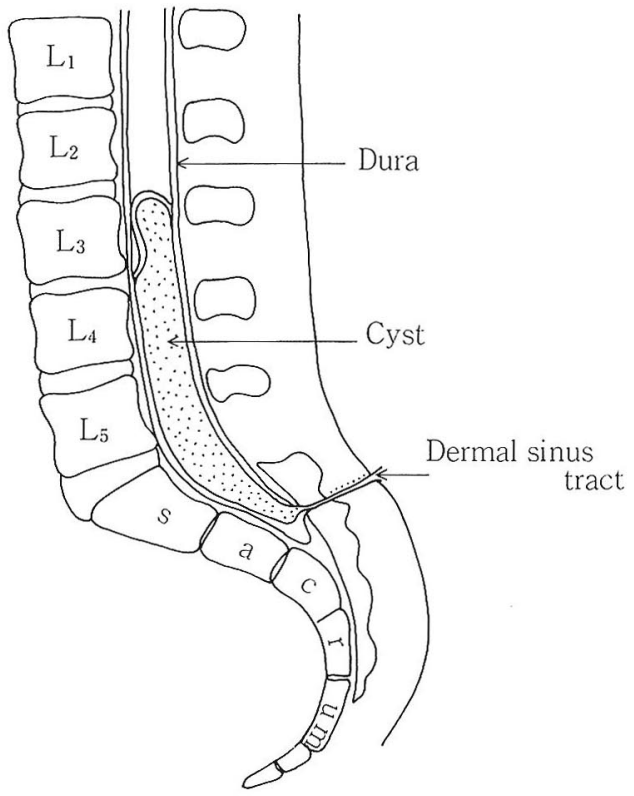

図 3 Diagram of the relationships of dermal sinus and cyst

術後 5 日間自尿が認められなかったが, ベット上で 約 4 週間安静後コルセットを装着, 現在術後 7 力月で あるが脊椎運動制限も改善され順調な経過を経てい る.

考

察

Congenital dermal sinus の発生機転は Bostr- 
öem²) (1897) の胎生学的研究によれば, 脳胞形成期 ないし髄管閉鎤期に当たる胎生第 $3 \sim 5$ 週が迷入時期 と考えられ，乙の時期に外胚葉が神経系外胚葉と皮䖉 系外胚葉に分化する際, 神経系外胚葉より神経溝が閉 じて神経管を形成するが，乙こで何等かの異常がおこ り一部の閉鎖が遅れるか不完全となり皮膚系外胚葉が 迷入し, 頭蓋ないし脊椎管内に表皮様腫あるいは皮様 腫を生ずる.またとの時皮膚系外胚葉の閉鎖不全によ り dermal sinus となる ${ }^{6) 7}$. 乙の際中胚葉より生ず る脊惟の形成不全がおこれば脊椎披裂を合併する.

本邦の 14 例に対しその臨床症状などを検討したと ころ, 発見年令は 2 力月から 35 才までの平均 9.8 才 であり，また List ${ }^{14)}$ あほとんどが5才前に発見され るという.その理由として， C. D. S. はしばしば二 次感染を起こす故に発見が早いと述べている. 本邦例 でも松角 ${ }^{17)}$ の症例を除き，すでに，以前に本症を疑 わしむる臨床症状を呈しており, 発見ないし発症年令 は低くなると思われる. 性別は男性 10 例, 女性 4 例 で症例数が少ないため決め難いが, Sachs ${ }^{21)}$ は22 例 に対して, 男性 15 例女性 7 例を認め, 一般に男性に 多いようである. 局所所見では, 背部皮膚正中線上に 色素沈着を 8 例 $57 \%$ ，多毛を 6 例 $43 \%$ に認め，そ の中央部に皮膚陷凹を有し C. D. S. が存在する.

C. D. S. の発生部位は腰椎下部 3 例, 腰仙椎部 5 例, 仙椎部 2 例, 胸椎部 2 例, 後頭部 2 例であり腰椎下部 より仙惟部にかけて高頻度に発生するようであり, 欧 米でも腰・仙惟部に集中している. Sinus は一部閉塞 し皮膚と脊惟管内腫偒との連絡をたっているものや, 開放状態で髄液の流出あるいは排膿を認めるあのまで 存在しており, 開放状態にある症例では髄膜炎を 10 例，更に C. D. S. が頭蓋ないし脊惟管内に貫通し皮 様腫や表皮様腫之直結し皮様腫 11 例表皮様腫 3 例を 認め, 神経圧迫症状をきたした症例は 4 例であった。 またその他の先天性異常として尿道下裂 1 例, 牛眼 1 例の合併をみる，X線所見では脊惟披裂を 6 例，頭蓋 骨に小孔を 2 例に，また椎弓根間距離の拡大を 1 例に 認める. 以上の如く文献上の臨床症状及びX 線所見を 参考にすれば診断は容易である. すなわち通常局所所 見として背部皮䖉正中線上に多毛を伴う色素沈着を有 し，血管腫，皮膚陥凹及び皮䖉洞が認められ，洞が感 染門戸となり髄膜刺激症状を，また頭蓋ないし脊椎管 内の腫痬による神経圧迫症状を呈する. X 線所見では 腫瘍による椎弓根間距離の拡大, C. D. S. に脊椎披
裂ないし 頭蓋骨小孔が Haworth ${ }^{7}$ によれば 14 例中 4 例に，また本邦でも 14 例中 8 例に認められる如く， 中胚葉の形成不全による脊椎披裂, 棘突起の配列の乱 れや時に脊椎の癒合などが認められる. また, ミェロ グラムにより脊椎管内腫瘍の存在を知り得る.

治療方針 手術適応について諸氏の意見があり， Mount ${ }^{16)}$ は感染症が 現われるのはほとんどの報告例 で 5 才以下であるとし, また Matson ${ }^{15)}$, Sachs ら ${ }^{211}$ あ同様の見解を述べている. そこで Walker は生後 皮覤正中線上に Sinus があって分泌物の流出をみる 場合は早期に切除して根元を断つことを奖めている. 演者らあ本邦に於いて C. D. S. の存在する 14 例中 C. D. S. が感染門戸となり 10 例 $71 \%$ に髅膜炎を合 併し重篤な後遺症を残し，また一旦葡膜炎に羅患すれ ばその治療は困難を極め不幸な結果を招くことも少な くない以上予防的手術適応を考膚して可及的早期の全 摘出術が望ましいと考える.

\section{結語}

C. D. S. を伴った馬尾神経皮様腫に対し 椎弓切除 術及び腫瘍摘出術を施行, 現在術後 7 力月でコルセッ 卜装着中であるが, 脊椎運動の改善も認め良好な結果 を得ている.

\section{文献}

1) Amader, L. V., Hankinson, J. and Bigler, J. A. : Congenital dermal sinuses J. Pediat., 47 : 300-310, 1955.

2) Boströem : Zbl, Allg. Path. U. Path. Anat., 8: 1, 1897.

3）白倉義則・他：胸椎破裂を伴った硬膜外および 髄内にわたる多発性皮様のう腫の 1 例. 整形外 科, 13: 3034-08, 1962 .

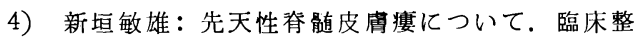
外科, 3: 145-154, 1968.

5) 福田道隆・他：皮下ょり硬膜内まで続いていた 皮様のう腫の 1 例. 東北整災外科記要, 7:4852, 1963.

6) Hamilton, Boyd, Mossman: Human Embryology. Third Edition, 315-317.

7) Haworth, J. C., Zacshary, R. B. : Congenital dermal sinuses in children, their relation to pilonidal sinuses. Lancet, 269: 10-14, 1955.

8) Hodges, R. H.: Boston Med. Surg. J., 103: 485, 1880.

9）石井鐐二・他：Spinal dermal sinus を伴っ 
た胸部盈道内皮様のう畽の 1 例. 臨床整形外科, 12: 998-1002, 1977.

11）木村正己・他：皮膚瘻を伴った胸椎部皮様のう 腫の 1 例. 中部整災誌, 2: 1016-1019, 1959.

12）小島正典・他：反復せる咀膜炎の原因となった Congenital dermal sinus の手術治験例. 小児 科診療, $21: 1257-1261,1958$.

13）小早川裕明・他幼児の難治性䯣膜炎に関与した Congenital dermal sinus tract の 1 例. 中部 整災誌, 21：1254-1255, 1978.

14) List, C. F.: Intraspinal epidermoid, dermoid, and dermal sinuses Surg. Gyn. and Obst., 73: 525-538, 1941.

15) Matson, D. D. et al.: Intracranial complications of congenital dermal sinuses. Pediatrics, 8: 463-474, 1952.

16) Mount, L. A.: Congenital dermal sinuses as a cause of meningitis, intraspinal abscess and intracranial abscess. J. A. M. A., 139: 1263-1268, 1949.

17）松角康彦 - 他: Congenital Dermal Sinus と 脳脊䯣病変。脳と神経, 21:35-42, 1969.

18）丸茂三千穂 - 他：春椎管内の Epidermoid Cyst と交通のあった Congenital Spinal Dermal Sinus の感染に基く椎管内膿瘄の 1 例. 小 児科診療，21：261-266, 1958.

19) Nelson, M.: Text book of Pediatrics 6th edition 714-1177, 1956.

20）西田和男・他：中枢神経障害を合併する先天性 皮覤洞について。脳と発達，4：186-190，1972.

21) Sachs, E. \& Horrax, G.: A ceruical and lumbar pilonidal sinus Complicating with intraspinal dermoids.: Report of 2 cases and review of the litarature. J. Neurosurg. 6: 97-112, 1942 .

22) Sharpe, W., Sharpe, N.: Neurosurgery; Principles, Diagnosis and Treatment, Philadelphia J. B., Lippincot Company, 1929.

23）都築暢之・他：腰部瘦孔を有し硬膜内膿瘍を形 成した馬尾神経皮様腫の 1 例. 医療，22：126$130,1968$.

24）宇田川英一：脊殉表皮样のう腫に続発したと思 われる脊髄硬膜下膿瘍の 1 例. 日整会勍, 31 : 181-184, 1957.
25）安井敬裕・他：Dermal sinus 92 例. 中部整 災誌, 21 : 1256-1258, 1978.

䁲 問 九州がんセンター 北島俊 裕 毛髪の生じた場所つまり体外から中に入ったのか, 体内で生じたのか.

\section{質 問広島大学 岩 森洋}

腰仙部の Dermal sinus は神経管内まで達しない 比較的浅いものが多いと思われますが, Meningitis, や神経症状のみられない症例でも予防的に切除した方 がよいと御考えですか.

\section{質 問 長崎市立市民病院 江 川 正} 広範囲にわたる小児の椎弓切除術後効題になるの は, 術後の脊椎不安定であるが, 当初, 装具を着用す ることが多いと思われるが，その着用期間について.

\section{回 答山口大学 河 合 伸 也}

若年者では一般に広範囲椎弓切除を施行した後には 彎曲異常が発生しやすいので，十分注意を要します. しかし彎曲異常の出現は椎弓切除の部位，範囲等によ って異なりますので, case by case で考えていく必 要があり私達も一定のプログラムはもちあわせていま せん. 術後には厳重に神経症状，X線所見を参考にし て追跡していくつもりです.

\section{質 問 鳥大整形 山 本 清 司}

(1) Dermoid cyst に合併した nerergitisは，重 症になるとおっしゃいましたか，その感染れ経路は， dermal sinus からとお考えでしょうか.

(2) Dernoid cyst の erigin は, embryalog ccal enore だけとお考えですか.

頻回の lunbal punctm をうけた既往を持つ症例の 報告を散見しますか. 